\title{
Seedling growth of fifteen Brazilian tropical tree species differing in successional status
}

\author{
ROGÉRIA P. SOUZA ${ }^{1}$ and IVANY F.M. VÁLIO ${ }^{1,2}$
}

(received: May 5, 2002; accepted: October 16, 2002)

\begin{abstract}
Seedling growth of fifteen Brazilian tropical tree species differing in successional status). Growth of seedlings of fifteen tropical tree species representative, at the adult stage, of different successional positions, was studied under field conditions. Seedlings were grown in three treatments: full sun (FS), artificial shade imposed by neutral screens (AS) and natural shade imposed by a closed canopy in a Forest Reserve in Southeast Brazil (NS). Most of the studied species survived in both shade treatments, although their growth was severely affected. Decreases in height, internode numbers, dry weight, leaf area, root:shoot ratio (R:S) and increases in leaf mass ratio (LMR), leaf area ratio (LAR) and specific leaf area (SLA) were common responses to shade. Relative growth rates (RGRs) and net assimilation rates (NARs) were consistently lower in the shaded treatments than in full sun. RGR was significantly correlated with NAR in the FS and NS treatments, whereas it was correlated with LAR in the AS treatment. Natural shade had more severe effects than artificial shade on leaf area reduction and RGR. Between-species differences in R:S, LMR, SLA and LAR were not related to the successional status of species. However, there was a tendency for early-successional species to have higher RGRs than late successional ones, regardless of the light environment. Late-successional species also showed less pronounced responses to shade than early ones. The characteristics presented by the late-successional species may be associated with shade tolerance, enabling their persistence under dense canopies.
\end{abstract}

Key words - Seedling growth, shade, shade tolerance, successional species, tropical tree species

RESUMO - (Crescimento de plântulas de quinze espécies árboreas tropicais pertencentes a diferentes estádios sucesionais). O crescimento de plântulas de quinze espécies arbóreas tropicais pertencentes a diferentes estádios sucessionais foi estudado sob condições de campo. As plântulas foram cultivadas sob tratamentos de radiação plena, sombreamento artificial proporcionado por telas sombrite e sombreamento natural imposto por dossel vegetal na Reserva Municipal de Santa Genebra em Campinas, SP, Brasil. A maioria das espécies estudadas sobreviveu aos tratamentos de sombreamento, com marcantes alterações no crescimento. Reduções de altura, número de entrenós, massa seca, área foliar e razão raiz/parte aérea (R/PA) foram respostas freqüentes ao sombreamento, assim como também aumentos da razão de massa foliar (RMF), razão de área foliar (RAF) e área foliar específica (AFE). As taxas de crescimento relativo (TCRs) e as taxas de assimilação líquida (TALs) apresentaram-se consistentemente mais baixas nos tratamentos de sombreamento. TCR se mostrou significativamente correlacionada com TAL nos tratamentos de radiação plena e sombreamento natural e com RAF no tratamento de sombreamento artificial. O sombreamento natural teve efeitos mais severos na redução da área foliar e da TCR. As diferenças inter-específicas nos parâmetros R/PA, RMF, AFE e RAF não se mostraram correlacionadas com o estádio sucessional. Foi observada uma tendência das espécies de estádios iniciais de sucessão apresentarem maiores TCRs do que as espécies tardias, independentemente do ambiente de luz. As espécies tardias apresentaram, em relação às iniciais, respostas menos pronunciadas ao sombreamento. As características apresentadas pelas espécies tardias podem estar associadas com tolerância à sombra, permitindo sua manutenção sob dosséis fechados por maiores períodos de tempo.

Palavras-chave - Crescimento de plântulas, espécies arbóreas tropicais, espécies sucessionais, sombreamento, tolerância ao sombreamento

\section{Introduction}

Within forest communities, light is a highly variable and often limiting resource (Chazdon \& Fetcher 1984) and is as a major factor affecting species replacement

\footnotetext{
1. Universidade Estadual de Campinas, Instituto de Biologia, Departamento de Fisiologia Vegetal, Caixa Postal 6109, 13083-970 Campinas, SP, Brasil.

2._Corresponding autor: ivalio@bol.com.br
}

during secondary succession (Bazzaz 1979). The degree of shade tolerance of species may be important in determining successional sequences, because these sequences are conditioned by the ability of species to establish and survive under the prevailing environmental conditions. Thus, early-successional species are considered to be shade-intolerant, because they require full sunlight for seedling establishment and growth, whereas climax or late-successional species are considered to be shade-tolerant, because they are able 
to establish and survive under the forest canopy (Swaine $\&$ Whitmore 1988). However, despite this usually used dichotomic classification in shade tolerance or intolerance, there are species that appear to be intermediate in their characteristics (Hartshorn 1980). Some results have shown that shade tolerance varies widely among species, so that the responses represent better a continuum of tolerance and not a dichotomy between opposite extremes (Augspurger 1984, Smith 1992, Souza \& Válio 2001).

Comparative studies have shown that early- and late-successional species differ with respect to several growth parameters, including relative growth rate, extension growth, leaf production, biomass allocation to root and leaves, specific leaf area and leaf area ratio (Ramakrishnan et al. 1982, Rao \& Singh 1989, Chandrashekara \& Ramakrishnan 1993, Walters et al. 1993, Kitajima 1994). In general, these studies have demonstrated that early-successional species have higher growth rates than late successional species, with less biomass allocation to the root system and larger leaf area ratio and specific leaf area. From an ecological point of view, such characteristics should facilitate a rapid occupation of space by pioneer and earlysuccessional species.

Several studies have examined the effect of shade on the growth of temperate and tropical tree species. However, although it is know that the spectral composition of radiation changes as it is filtered by green canopies, most studies on shade effects have been restricted to investigations of the effects of decreasing the photon flux density without ascribing for changes in spectral composition (Osunkoya \& Ash 1991, Thompson et al. 1992, Walters et al. 1993, Osunkoya et al. 1994, Bartlett \& Remphrey 1998, Reich et al. 1998). Exceptions are the studies of Kwesiga \& Grace (1986), Kitajima (1994), Tinoco-Ojanguren \& Pearcy (1995) and Lee et al. (1996), where natural shade was simulated under experimental conditions by reducing both photon flux density and red/far-red ratio. Although Kitajima (1994) found that reduced red/far-red ratio did not affect growth in any of the thirteen species studied, all of the other studies indicated that growth was significantly influenced by light quality, although the specific pattern of response varied among species. Popma \& Bongers $(1988,1991)$ evaluated growth of plants grown experimentally in gaps and under the forest canopy and exposed, therefore, to radiation differing in both photon flux density and red/far-red. Although such field studies do not allow discrimination between light quantity and light quality effects and are also subject to other variation in climatic factors, they may be of some advantage when interpreting the effects of shade on growth, because the shade-tolerance concept does not distinguish between these effects (Wang et al. 1994).

The aim of the present field study was to investigate the effects of shade on seedling growth of several tropical tree species differing in successional status.

\section{Materials and methods}

The species studied are listed in table 1 and hereafter they will be designated only by the genus name. These species are representative of different successional positions, whose characterization was based on the habitat distribution of species at the adult stage. Three categories were used: 1) early-successional, comprising those species that are absent from the understorey and usually found in large gaps or forest edges, 2) intermediate, comprising those species that occur under conditions of moderate shade, such as in small gaps, shaded forest edges or moderately shaded understories and 3) late successional, comprising the species usually found in the densely shaded understorey (Gandolfi et al. 1995). All of the species studied are native of a semideciduous tropical forest (Santa Genebra Reserve) in Campinas, SP, Brazil ( $22^{\circ} 44^{\prime} 45^{\prime \prime} \mathrm{S}$ and $47^{\circ} 06^{\prime} 33^{\prime \prime} \mathrm{W}$; $670 \mathrm{~m}$ altitude), where the field experiments were carried out. Seedlings were obtained from seeds collected from a number of different parent trees, which were either sowed in trays or germinated in incubators and then transferred to soil. In both cases, seedlings were kept in glasshouse for establishment. Once established, seedlings were transplanted in polyethylene bags $(3.5 \mathrm{~L})$ filled with soil of the forest floor. Only in the case of Pachystroma, recently emerged seedlings were collected in the forest; they were also kept in glasshouse until the beginning of the experiments.

At the beginning of the experiments, seedlings of each species were randomly assigned to four groups, one of which was immediately harvested to obtain initial growth parameters of height, internode number, dry mass and leaf area. Initial height and internode number values were also recorded for the other three groups, which were transferred to the Santa Genebra Reserve. Of these, one group was maintained outside the forest (full sun treatment, FS), and another was maintained in the forest understorey beneath a closed canopy (natural shade treatment, NS). An additional artificial shade treatment was carried out by maintaining a third group outside the forest in a wooden frame covered by four layers of $50 \%$ shade netting (artificial shade treatment, AS).

The PAR (photosynthetically active radiation, 400-700 nm) inside the forest (NS treatment) was ca. $0.4 \%$ to $2.4 \%$ of full sun, and red/far-red ratio (R:FR ratio calculated as the ratio of the spectral irradiance values at the wavelength band $656-664 \mathrm{~nm}$ to that at $726-734 \mathrm{~nm}$ ) varied 
Table 1. Species studied, classification according to the successional status $(\mathrm{E}=$ early-successional; $\mathrm{I}=$ intermediate, $\mathrm{L}=$ latesuccessional), seedling age at the beginning of experiments and growth period $(\mathrm{Sp}=$ spring, $\mathrm{Su}=\operatorname{summer}, \mathrm{A}=$ autumn$) \mathrm{under}$ the experimental conditions.

\begin{tabular}{|c|c|c|c|}
\hline Species & $\begin{array}{l}\text { Successional } \\
\text { status* }\end{array}$ & $\begin{array}{l}\text { Age } \\
\text { (days) }\end{array}$ & Growth period (Season of the year) \\
\hline Solanum granuloso-leprosum Dun. (Solanaceae) & $\mathrm{E}$ & 55 & 10-Nov to $19-\mathrm{Feb}(\mathrm{Sp}-\mathrm{Su})$ \\
\hline Trema micrantha (L.) Blum. (Ulmaceae) & $\mathrm{E}$ & 60 & 18-Nov to $26-\mathrm{Feb}(\mathrm{Sp}-\mathrm{Su})$ \\
\hline Cecropia pachystachya Trec. (Cecropiaceae) & $\mathrm{E}$ & 11 & 07-Mar to 17-Jun (Su-A) \\
\hline $\begin{array}{l}\text { Bauhinia forficata Link } \\
\quad \text { subsp. pruinosa (Vog.) Fortun. \& Wund. (Caesalpiniaceae) }\end{array}$ & $\mathrm{E}$ & 34 & $25-\mathrm{Oct}$ to $02-\mathrm{Feb}(\mathrm{Sp}-\mathrm{Su})$ \\
\hline Senna macranthera (Collad.) Irwin \& Barn. (Caesalpiniaceae) & $\mathrm{E}$ & 39 & $31-$ Oct to $08-\mathrm{Feb}(\mathrm{Sp}-\mathrm{Su})$ \\
\hline Schizolobium parahyba (Vell.) Blake (Caesalpiniaceae) & $\mathrm{E}$ & 40 & 18-Dec to 28-Mar (Su-A) \\
\hline Piptadenia gonoacantha (Mart.) Macbr. (Mimosaceae) & $\mathrm{E}$ & 43 & 21-Dec to 05-Mar (Su) \\
\hline Chorisia speciosa A. St.-Hil. (Bombacaceae) & I & 39 & 03-Nov to $11-\mathrm{Feb}(\mathrm{Sp}-\mathrm{Su})$ \\
\hline Pseudobombax grandiflorum (Cav.) A. Rob. (Bombacaceae) & I & 20 & 24-Nov to 03-Mar (Sp-Su) \\
\hline Ficus guaranitica Schodat (Moraceae) & $\mathrm{L}$ & 185 & 15-Nov to $23-\mathrm{Feb}(\mathrm{Sp}-\mathrm{Su})$ \\
\hline Esenbeckia leiocarpa Engl. (Rutaceae) & $\mathrm{L}$ & 47 & 02-Nov to $10-\mathrm{Feb}(\mathrm{Sp}-\mathrm{Su})$ \\
\hline Pachystroma longifolium (Nees) I.M. Johns. (Euphorbiaceae) & $\mathrm{L}$ & $* *$ & 11-Nov a $21-\mathrm{Feb}(\mathrm{Sp}-\mathrm{Su})$ \\
\hline Myroxylon peruiferum L. f. (Fabaceae) & $\mathrm{L}$ & 75 & 20-Mar to 28-Jun (A) \\
\hline Hymenaea courbaril L. (Caesalpiniaceae) & $\mathrm{L}$ & 49 & $05-\mathrm{Nov}$ to $13-\mathrm{Feb}(\mathrm{Sp}-\mathrm{Su})$ \\
\hline
\end{tabular}

* Classification according to: Gandolfi (1991), Lorenzi (1992), Mantovani (1993), Salis et al. (1994), Rodrigues (1995), Bernacci \& LeitãoFilho (1996); based upon the habitat distribution of species at adult stage.

** Unknown age: seedlings collected from the forest floor.

from 0.23 to 0.74 . This range of values was based on measurements made at different times of day $(8: 00 \mathrm{~h}, 12: 00 \mathrm{~h}$ and 16:00 h) in the different seasons of the year (on days next to the summer and winter solstice and to the spring and autumnal equinox). Under shade netting, irradiance was about $1.2 \%$ to $7.1 \%$ of full sun and $\mathrm{R} / \mathrm{FR}$ ratio varied from 0.84 to 1.39. The R:FR ratio of full radiation varied from 1.22 to

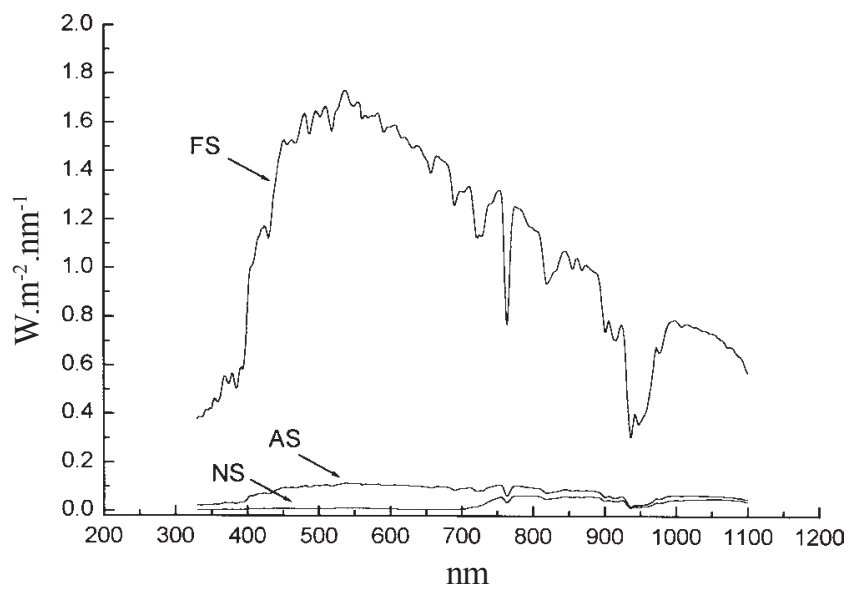

Figure 1. Spectral distributions of radiation obtained in early summer under full sun (FS), artificial shade (AS) and natural shade (NS) treatments.
1.44. In figure 1, the spectral distribution of radiation obtained in early summer in all the treatments is presented. All these radiation measurements were recorded by a Li-Cor spectroradiometer (LI-1800), with the sensor placed above the seedlings.

In the FS treatment, the polyethylene bags were buried in ditches to avoid excessive heating of the root system; the tops of the bags remained at the soil level. Plants in the FS and AS treatments were watered daily, whereas those in the NS treatment were watered every other day, if necessary, based on a visual and tactile evaluation of soil humidity. Seedlings of all studied species were grown for 100 days in the treatments and then harvested for final growth evaluation. Growth periods for each species, along with the related season, as well as seedling age, are indicated in table 1. The temperatures in the FS, AS and NS treatments varied, respectively, from $13{ }^{\circ} \mathrm{C}-41^{\circ} \mathrm{C}, 14^{\circ} \mathrm{C}-33^{\circ} \mathrm{C}$ and $14^{\circ} \mathrm{C}-28^{\circ} \mathrm{C}$ during spring, from $12^{\circ} \mathrm{C}-46^{\circ} \mathrm{C}, 13^{\circ} \mathrm{C}-40^{\circ} \mathrm{C}$ and $13{ }^{\circ} \mathrm{C}-30^{\circ} \mathrm{C}$ during summer and from $8{ }^{\circ} \mathrm{C}-38^{\circ} \mathrm{C}, 10^{\circ} \mathrm{C}-37^{\circ} \mathrm{C}$ and $11^{\circ} \mathrm{C}-$ $26^{\circ} \mathrm{C}$ during autumn.

Plant height, internode number, dry mass and leaf area were recorded as growth parameters. Mean internode length was calculated by height/internode number. Dry mass was measured after drying at $80^{\circ} \mathrm{C}$ for $48 \mathrm{~h}$. Leaf area was determined gravimetrically, by weighing a cut out paper trace of the leaves and comparing their mass to known standards (pieces of paper with known area). In 
the case of the Schizolobium and Piptadenia species with bipinnate leaves, only 15 leaflets per plant were outlined and, by counting the total leaflet number, the total leaf area was estimated. Subsequent comparison of the gravimetric method with the leaf area determination method through scanner-generated images indicated a good agreement between values (within 6\% error, except for Schizolobium and Piptadenia, where errors were $+12.7 \%$ and $-7.4 \%$, respectively).

From the primary data, the following parameters were derived: root:shoot ratio (R:S, root dry mass/shoot dry mass), leaf mass ratio (LMR, leaf dry mass/total dry mass), specific leaf area (SLA, leaf area/leaf dry mass) and leaf area ratio (LAR, leaf area/total dry mass). Mean relative growth rate (RGR) and net assimilation rate (NAR) were calculated by: $R G R=\left(\ln W_{2}-\ln W_{1}\right) /\left(t_{2}-t_{1}\right)$ and $N A R=\left[\left(W_{2}-W_{1}\right) /\left(t_{2}-\right.\right.$ $\left.\left.t_{1}\right)\right] \times\left[\left(\ln A_{2}-\ln A_{1}\right) /\left(A_{2}-A_{1}\right)\right]$, where $\mathrm{W}=$ dry mass, $\mathrm{A}=$ leaf area and $\mathrm{t}=$ time, with index $\mathrm{x}_{1}=$ initial values and index $\mathrm{x}_{2}=$ final values (Hunt 1982).

Prior to statistical analysis, data were tested for homogeneity of variances and for normal distribution by, respectively, Bartlett's test and Kolmogorov-Smirnov test as modified by Lilliefors (1967). Where necessary, log or squareroot transformation of data were used. In all cases where the above assumptions of parametric analysis were met or achieved by means of data transformation, comparisons of means were made by the Student's t test or an analysis of variance (one-way ANOVA) followed, when appropriate, by post-hoc comparisons using Tukey's test, at the 5\% probability level. Otherwise, data were expressed as medians and were analysed by non-parametric techniques, through Wilcoxon's test or Kruskal-Wallis test at the 5\% probability level.

\section{Results}

Survival and growth in shade - Most of the studied species had high survival rates $(80 \%-100 \%)$ in the shade treatments. Survival rates were low for Solanum in AS (0\%) and for Trema, Pseudobombax, Pachystroma and Senna in NS $(14.3 \%, 25.0 \%, 40.0 \%$ and $57.1 \%$, respectively).

In general, growth was lower in the shade treatments compared with the FS treatment, with plants showing lower height, internode number, total dry mass and total leaf area (table 2).

Despite the differences in irradiance between AS and NS treatments, their effects on seedling dry mass were not statistically different, save the cases of Cecropia, Ficus and Esenbeckia. In contrast, leaf area values were smaller in NS than in AS for most species. The AS and NS treatments had no consistent effect on height and internode number. In some species, these parameters were similar in both shade treatments (e.g., in Bauhinia, Schizolobium, Piptadenia, Myroxylon), whereas in other species, both parameters (e.g., in Cecropia, Esenbeckia) or only one of them (e.g., in Senna, Pachystroma, Hymenaea) were lower in the NS treatment. In Chorisia and Ficus, the AS and NS treatments had even opposite effects on plant height. In Chorisia, the NS treatment reduced whereas the AS treatment increased height growth, even though internode number was reduced in both shade treatments. In Ficus, AS had no effect on height growth, whereas NS promoted height growth; internode number was reduced similarly in both treatments (table 2). By calculating the mean internode length as the ratio height/ internode number, internode elongation under shade was detected, mainly in the NS treatment, in Chorisia, Ficus, Esenbeckia, Pachystroma, Myroxylon and Hymenaea, all species belonging to intermediate or late successional stages (table 3). At least for the latter four species, the internode number was reduced proportionally more than height (table 2 ), resulting in the detection of elongation. In early successional species, in general, both height and internode number were proportionally reduced, resulting in no elongation, or height was severely reduced, reflecting in a reduction in internode elongation in the shade treatments (table 3 ).

The shade treatments decreased R:S in most species (figure 2A). However, if only the five late-successional studied species were taken into account, it could be observed that R:S was not affected by shade in three of them (Esenbeckia, Pachystroma and Myroxylon). Higher LMR, SLA and LAR were observed in shade treatments in most species (figures $2 \mathrm{~B}, \mathrm{C}, \mathrm{D}$ ). In contrast, Pachystroma showed lower LMR and LAR in NS. In most cases, AS and NS treatments had similar effects. When not similar, however, no regular pattern of variation could be defined.

Both RGR and NAR were consistently lower in shaded than in sun-exposed seedlings (figure 3 ). In some species, RGR and NAR were more affected by NS treatment than by AS treatment. RGR in FS and NS showed a strong positive correlation with NAR, but no significant correlation with LAR. However, in AS, the opposite pattern was found, i.e., RGR correlated well with LAR but not with NAR (figure 4). In all cases, LAR was positively correlated with SLA as well as with LMR (figure 4).

Species responses in relation to the successional status - The early-successional species Trema showed the greatest increases in height, internode number, dry mass and leaf area in relation to the initial values, mainly 
Table 2. Growth parameters obtained from plants of the studied tree species. Measurements at the beginning of the experiments $(\mathrm{IV}=$ initial values) and after 100 days under full sun (FS), artificial shade (AS) and natural shade (NS) treatments. (N= sample size). Internode number does not include hypocotyl; leaf area does not include cotyledon area. Means or medians followed by the same letters are not significantly different.

\begin{tabular}{|c|c|c|c|c|c|c|}
\hline Species & Treatment & $\mathrm{N}$ & $\begin{array}{l}\text { Height } \\
(\mathrm{cm})\end{array}$ & Internode number & $\begin{array}{l}\text { Total dry mass } \\
(\mathrm{g})\end{array}$ & $\begin{array}{l}\text { Leaf area } \\
\left(\mathrm{cm}^{2}\right)\end{array}$ \\
\hline \multirow[t]{4}{*}{ Solanum } & IV & 5 & $3.30( \pm 0.65)^{1}$ & $5.0( \pm 0.3)$ & $0.067( \pm 0.017)$ & $15.19( \pm 4.10)$ \\
\hline & FS & 5 & $15.98 \mathrm{a}$ & $14.0 \mathrm{a}$ & $8.442 \mathrm{a}$ & $622.30 \mathrm{a}$ \\
\hline & AS & - & - & - & - & - \\
\hline & NS & 5 & $9.82 \mathrm{a}$ & $10.8 \mathrm{~b}$ & $0.119 \mathrm{~b}$ & $26.73 \mathrm{~b}$ \\
\hline \multirow[t]{4}{*}{ Trema } & $\mathrm{IV}$ & 5 & $1.98( \pm 0.10)$ & $1.8( \pm 0.4)$ & $0.015( \pm 0.004)$ & $2.40( \pm 0.76)$ \\
\hline & FS & 5 & $49.93 \mathrm{a}$ & $19.0 \mathrm{a}$ & $8.504 \mathrm{a}$ & $858.02 \mathrm{a}$ \\
\hline & AS & 5 & $21.26 \mathrm{~b}$ & $14.6 \mathrm{~b}$ & $0.736 b$ & $318.60 \mathrm{~b}$ \\
\hline & NS & - & - & - & - & - \\
\hline \multirow[t]{4}{*}{ Cecropia } & $\mathrm{IV}$ & 12 & $5.00( \pm 0.11)$ & $8.7( \pm 0.3)$ & $0.320( \pm 0.015)$ & $73.00( \pm 3.60)$ \\
\hline & FS & 12 & $36.13 \mathrm{a}$ & $19.4 \mathrm{a}$ & $22.004 \mathrm{a}$ & $1576.20 \mathrm{a}$ \\
\hline & AS & 12 & $26.53 b$ & $15.9 \mathrm{~b}$ & $2.330 \mathrm{~b}$ & $797.88 \mathrm{a}$ \\
\hline & NS & 12 & $15.61 \mathrm{c}$ & $11.4 \mathrm{c}$ & $0.757 \mathrm{c}$ & $204.50 \mathrm{~b}$ \\
\hline \multirow[t]{4}{*}{ Bauhinia } & IV & 13 & $5.32( \pm 0.28)$ & $2.2( \pm 0.1)$ & $0.130( \pm 0.009)$ & $20.33( \pm 2.28)$ \\
\hline & FS & 13 & $44.55 \mathrm{a}$ & $19.9 \mathrm{a}$ & $8.399 \mathrm{a}$ & $585.76 \mathrm{a}$ \\
\hline & AS & 13 & $14.34 b$ & $7.9 \mathrm{~b}$ & $0.444 b$ & $153.45 b$ \\
\hline & NS & 13 & $16.00 \mathrm{~b}$ & $8.3 \mathrm{~b}$ & $0.656 \mathrm{~b}$ & $160.41 \mathrm{~b}$ \\
\hline \multirow[t]{4}{*}{ Senna } & $\mathrm{IV}$ & 10 & $3.13( \pm 0.32)$ & $1.6( \pm 0.2)$ & $0.060( \pm 0.007)$ & $10.36( \pm 1.80)$ \\
\hline & FS & 10 & $13.79 \mathrm{a}$ & $10.1 \mathrm{a}$ & $2.215 \mathrm{a}$ & $218.43 \mathrm{a}$ \\
\hline & AS & 10 & $9.19 \mathrm{~b}$ & $7.3 \mathrm{~b}$ & $0.278 b$ & $114.10 \mathrm{~b}$ \\
\hline & NS & 8 & $6.74 \mathrm{~b}$ & $4.5 \mathrm{c}$ & $0.063 \mathrm{~b}$ & $20.35 \mathrm{c}$ \\
\hline \multirow[t]{4}{*}{ Schizolobium } & $\mathrm{IV}$ & 7 & $12.93( \pm 1.86)$ & $2.7( \pm 0.3)$ & $0.460( \pm 0.123)$ & $82.60( \pm 20.42)$ \\
\hline & FS & 7 & $56.30 \mathrm{a}$ & $11.6 \mathrm{a}$ & $36.790 \mathrm{a}$ & $2590.70 \mathrm{a}$ \\
\hline & AS & 7 & $35.21 \mathrm{~b}$ & $7.7 b$ & $2.579 \mathrm{~b}$ & $502.02 \mathrm{~b}$ \\
\hline & NS & 7 & $29.10 \mathrm{~b}$ & $6.9 \mathrm{~b}$ & $1.222 \mathrm{~b}$ & $244.13 \mathrm{c}$ \\
\hline \multirow[t]{4}{*}{ Piptadenia } & IV & 5 & $5.28( \pm 0.53)$ & $3.6( \pm 0.3)$ & $0.070( \pm 0.013)$ & $12.10( \pm 2.02)$ \\
\hline & FS & 5 & $38.26 \mathrm{a}$ & $13.8 \mathrm{a}$ & $2.452 \mathrm{a}$ & $416.37 \mathrm{a}$ \\
\hline & AS & 5 & $9.64 \mathrm{~b}$ & $8.2 \mathrm{~b}$ & $0.339 b$ & $111.79 \mathrm{~b}$ \\
\hline & $\mathrm{NS}$ & 5 & $6.52 \mathrm{~b}$ & $6.6 \mathrm{~b}$ & $0.099 \mathrm{~b}$ & $26.81 \mathrm{~b}$ \\
\hline \multirow{4}{*}{ Chorisia } & IV & 12 & $8.49( \pm 0.42)$ & $1.8( \pm 0.1)$ & $0.290( \pm 0.023)$ & $21.17( \pm 1.70)$ \\
\hline & FS & 12 & $27.77 \mathrm{~b}$ & $14.5 \mathrm{a}$ & $7.976 \mathrm{a}$ & $519.57 \mathrm{a}$ \\
\hline & AS & 12 & $33.07 \mathrm{a}$ & $11.4 \mathrm{~b}$ & $2.074 \mathrm{~b}$ & $522.34 \mathrm{a}$ \\
\hline & NS & 12 & $20.49 \mathrm{c}$ & $6.8 \mathrm{c}$ & $0.835 \mathrm{~b}$ & $178.15 \mathrm{~b}$ \\
\hline \multirow[t]{4}{*}{ Pseudobombax } & IV & 7 & $2.49( \pm 0.38)$ & $0.4( \pm 0.2)$ & $0.090( \pm 0.008)$ & $1.96( \pm 0.31)$ \\
\hline & FS & 7 & $9.61 \mathrm{a}$ & $7.0 \mathrm{a}$ & $3.587 \mathrm{a}$ & $303.71 \mathrm{a}$ \\
\hline & AS & 7 & $7.11 \mathrm{a}$ & $4.1 \mathrm{~b}$ & $0.424 b$ & $61.46 \mathrm{a}$ \\
\hline & NS & - & - & - & - & - \\
\hline \multirow[t]{4}{*}{ Ficus } & IV & 10 & $5.42( \pm 0.27)$ & $10.2( \pm 0.4)$ & $1.890( \pm 0.194)$ & $106.99( \pm 8.03)$ \\
\hline & FS & 10 & $13.50 \mathrm{~b}$ & $17.8 \mathrm{a}$ & $9.859 \mathrm{a}$ & $394.51 \mathrm{a}$ \\
\hline & AS & 10 & $12.14 \mathrm{~b}$ & $14.6 \mathrm{~b}$ & $4.715 b$ & $384.24 \mathrm{a}$ \\
\hline & NS & 9 & $21.68 \mathrm{a}$ & $13.7 \mathrm{~b}$ & $2.096 \mathrm{c}$ & $195.75 \mathrm{~b}$ \\
\hline \multirow[t]{4}{*}{ Esenbeckia } & $\mathrm{IV}$ & 13 & $6.15( \pm 0.25)$ & $1.0( \pm 0.0)$ & $0.100( \pm 0.005)$ & $8.73( \pm 0.58)$ \\
\hline & FS & 13 & $11.01 \mathrm{a}$ & $7.6 \mathrm{a}$ & $0.662 \mathrm{a}$ & $112.46 \mathrm{a}$ \\
\hline & AS & 13 & $10.73 \mathrm{a}$ & $5.8 \mathrm{~b}$ & $0.328 \mathrm{a}$ & $78.99 a$ \\
\hline & NS & 13 & $8.39 \mathrm{~b}$ & $3.8 \mathrm{c}$ & $0.116 \mathrm{~b}$ & $27.85 b$ \\
\hline
\end{tabular}


(cont.)

\begin{tabular}{lcrcccc}
\hline Species & Treatment & $\mathrm{N}$ & $\begin{array}{c}\text { Height } \\
(\mathrm{cm})\end{array}$ & Internode number & $\begin{array}{c}\text { Total dry mass } \\
(\mathrm{g})\end{array}$ & $\begin{array}{c}\text { Leaf area } \\
\left(\mathrm{cm}^{2}\right)\end{array}$ \\
\hline Pachystroma & IV & 10 & $9.35( \pm 0.40)$ & 0.0 & $0.180( \pm 0.018)$ & 0.00 \\
& FS & 9 & $9.83 \mathrm{a}$ & $5.3 \mathrm{a}$ & $1.121 \mathrm{a}$ & $76.36 \mathrm{a}$ \\
& $\mathrm{AS}$ & 10 & $8.42 \mathrm{a}$ & $2.5 \mathrm{~b}$ & $0.384 \mathrm{~b}$ & $27.70 \mathrm{a}$ \\
& $\mathrm{NS}$ & 4 & $8.25 \mathrm{a}$ & $1.0 \mathrm{c}$ & $0.188 \mathrm{~b}$ & $6.59 \mathrm{~b}$ \\
\hline Myroxylon & $\mathrm{IV}$ & 5 & $10.04( \pm 0.38)$ & $3.0( \pm 0.3)$ & $0.330( \pm 0.058)$ & $35.1( \pm 4.55)$ \\
& $\mathrm{FS}$ & 5 & $13.43 \mathrm{a}$ & $6.6 \mathrm{a}$ & $1.127 \mathrm{a}$ & $33.98 \mathrm{a}$ \\
& $\mathrm{AS}$ & 5 & $10.34 \mathrm{~b}$ & $4.0 \mathrm{~b}$ & $0.344 \mathrm{~b}$ & $13.49 \mathrm{ab}$ \\
& $\mathrm{NS}$ & 5 & $1054 \mathrm{~b}$ & $3.0 \mathrm{~b}$ & $0.306 \mathrm{~b}$ & $10.95 \mathrm{~b}$ \\
\hline Hymenaea & $\mathrm{IV}$ & 10 & $16.71( \pm 0.80)$ & $2.2( \pm 0.1)$ & $1.510( \pm 0.123)$ & $81.05( \pm 8.41)$ \\
& $\mathrm{FS}$ & 10 & $40.91 \mathrm{a}$ & $10.0 \mathrm{a}$ & $8.636 \mathrm{a}$ & $472.19 \mathrm{a}$ \\
& $\mathrm{AS}$ & 10 & $30.17 \mathrm{~b}$ & $6.6 \mathrm{~b}$ & $2.446 \mathrm{~b}$ & $273.27 \mathrm{~b}$ \\
& $\mathrm{NS}$ & 10 & $21.44 \mathrm{~b}$ & $4.1 \mathrm{c}$ & $1.725 \mathrm{~b}$ & $152.40 \mathrm{c}$ \\
\hline
\end{tabular}

${ }^{1}$ Mean ( \pm standard error)

under FS conditions (table 2). For instance, the final dry mass value under FS, after a 100-day growth period, represented an increase of $56,593.3 \%$ in relation to the initial value, whereas under AS the increase was of $4,807.0 \%$. Other early-successional species also presented, in relation to the initial values, great proportional increases in dry mass in FS treatments, e.g., Solanum (12,500.0\%), Schizolobium (7,897.8\%), Cecropia (6,776.3\%), and Bauhinia (6,360.8\%). On the other hand, late-successional species were characterized

Table 3. Mean internode length obtained from plants of the studied tree species under full sun (FS), artificial shade (AS) and natural shade (NS) treatments. Means or medians followed by same letters are not significantly different.

\begin{tabular}{lccc}
\hline Species & \multicolumn{3}{c}{ Mean internode length $(\mathrm{cm})$} \\
\cline { 2 - 4 } & $\mathrm{FS}$ & $\mathrm{AS}$ & $\mathrm{NS}$ \\
\hline Solanum & $1.06 \mathrm{a}$ & - & $0.88 \mathrm{a}$ \\
Trema & $2.28 \mathrm{a}$ & $1.43 \mathrm{~b}$ & - \\
Cecropia & $1.85 \mathrm{a}$ & $1.67 \mathrm{a}$ & $1.36 \mathrm{~b}$ \\
Bauhinia & $2.14 \mathrm{a}$ & $1.78 \mathrm{~b}$ & $1.94 \mathrm{ab}$ \\
Senna & $1.34 \mathrm{a}$ & $1.26 \mathrm{a}$ & $1.51 \mathrm{a}$ \\
Schizolobium & $4.88 \mathrm{a}$ & $4.57 \mathrm{a}$ & $4.22 \mathrm{a}$ \\
Piptadenia & $2.73 \mathrm{a}$ & $1.17 \mathrm{~b}$ & $1.01 \mathrm{~b}$ \\
Chorisia & $1.98 \mathrm{~b}$ & $2.98 \mathrm{a}$ & $3.09 \mathrm{a}$ \\
Pseudobombax & $1.41 \mathrm{a}$ & $1.71 \mathrm{a}$ & - \\
Ficus & $0.77 \mathrm{~b}$ & $0.83 \mathrm{~b}$ & $1.60 \mathrm{a}$ \\
Esenbeckia & $1.45 \mathrm{c}$ & $1.88 \mathrm{~b}$ & $2.28 \mathrm{a}$ \\
Pachystroma & $1.85 \mathrm{c}$ & $3.50 \mathrm{~b}$ & $8.25 \mathrm{a}$ \\
Myroxylon & $2.27 \mathrm{~b}$ & $2.67 \mathrm{ab}$ & $3.72 \mathrm{a}$ \\
Hymenaea & $4.14 \mathrm{~b}$ & $4.52 \mathrm{~b}$ & $5.98 \mathrm{a}$ \\
\hline
\end{tabular}

by small increases in dry mass, as was the case for Esenbeckia (562.0\%), Pachystroma (522.8\%), Hymenaea (471.9\%), Ficus (421.64\%) and Myroxylon (241.5\%).

Comparison of the species based on FS values revealed no trends, such as smaller R:S or greater LMR, SLA and LAR, with the successional status (figure 2). Neither were trends apparent when the comparison was based on shade values. A small response to shade was evident for some late-successional species. In these species, for some parameters, no statistical differences were observed between FS and the shade treatments, e.g., for R:S in Esenbeckia, Pachystroma and Myroxylon, and for LMR in Myroxylon. Even when a statistical difference was found between FS and the shade treatments, the extent of the response was usually smaller for the late-successional species than for the early-successional ones. A comparison between the early-successional Cecropia and the late-successional Myroxylon indicates that Cecropia in NS showed an increase of $187.4 \%$ in SLA and of $260.9 \%$ in LAR, whereas the corresponding increases in Myroxylon were, respectively, of only $20.7 \%$ and of $30.1 \%$.

Considering RGR in FS, the ranking of species from the higher to the lower values was: Trema $>$ Schizolobium $>$ Solanum $>$ Bauhinia $>$ Cecropia $>$ Pseudobombax $>$ Piptadenia $>$ Senna $>$ Chorisia $>$ Esenbeckia $>$ Pachystroma $>$ Ficus $>$ Hymenaea $>$ Myroxylon. When considering RGR values in shade, although some species changed position in the ranking, the early-successional species, on the whole, still remained in the first positions (i.e., higher RGRs) and 

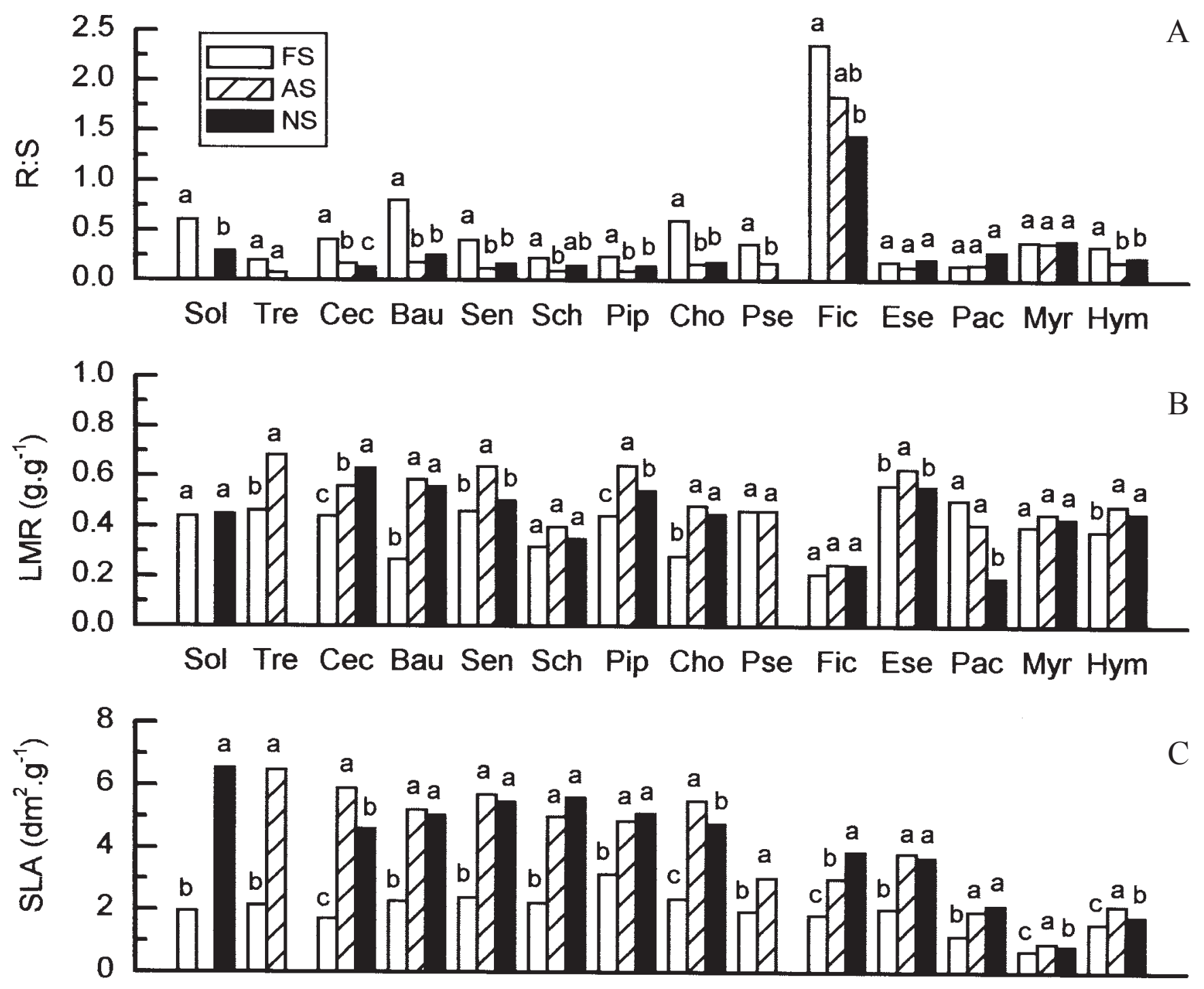

Sol Tre Cec Bau Sen Sch Pip Cho Pse Fic Ese Pac Myr Hym

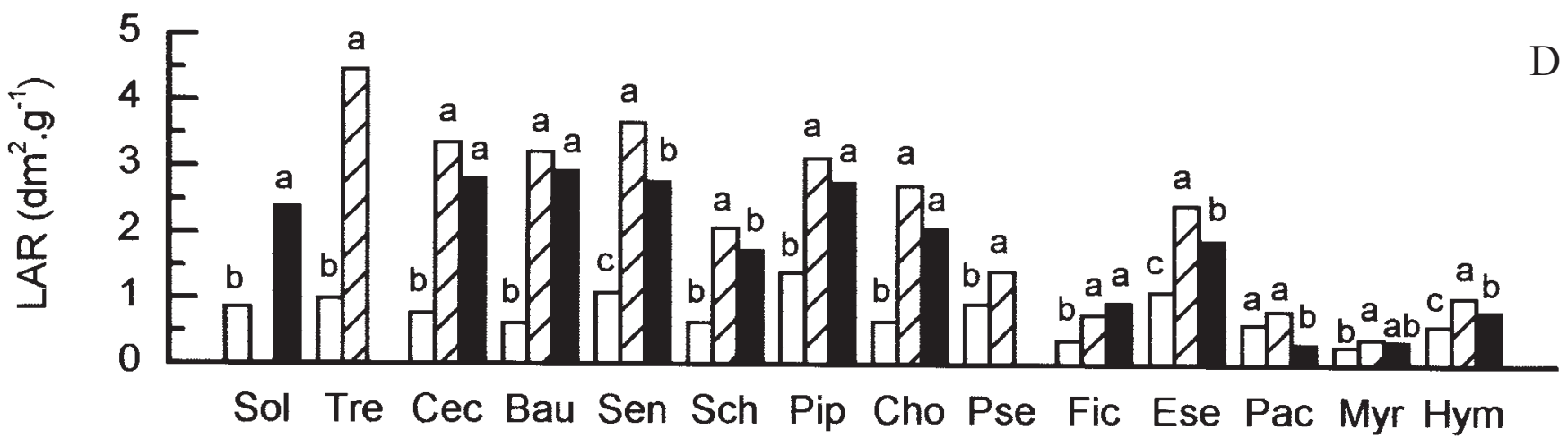

Species

Figure 2. A. Root:shoot ratio (R:S); B. leaf mass ratio (LMR); C. specific leaf area (SLA); and D. leaf area ratio (LAR) of the studied tree species under full sun (FS, $\square$ ), artificial shade (AS, $\square$ ), and natural shade (NS, $\square$ ) treatments. Measurements after 100 days. Sol $=$ Solanum, Tre $=$ Trema, $\mathrm{Cec}=$ Cecropia, Bau $=$ Bauhinia, Sen $=$ Senna, Sch $=$ Schizolobium, Pip $=$ Piptadenia, $\mathrm{Cho}=$ Chorisia, Pse $=$ Pseudobombax, Fic $=$ Ficus, Ese $=$ Esenbeckia, Pac $=$ Pachystroma, Myr $=$ Myroxylon, Hym $=$ Hymenaea . Values followed by the same letter are not significantly different. 


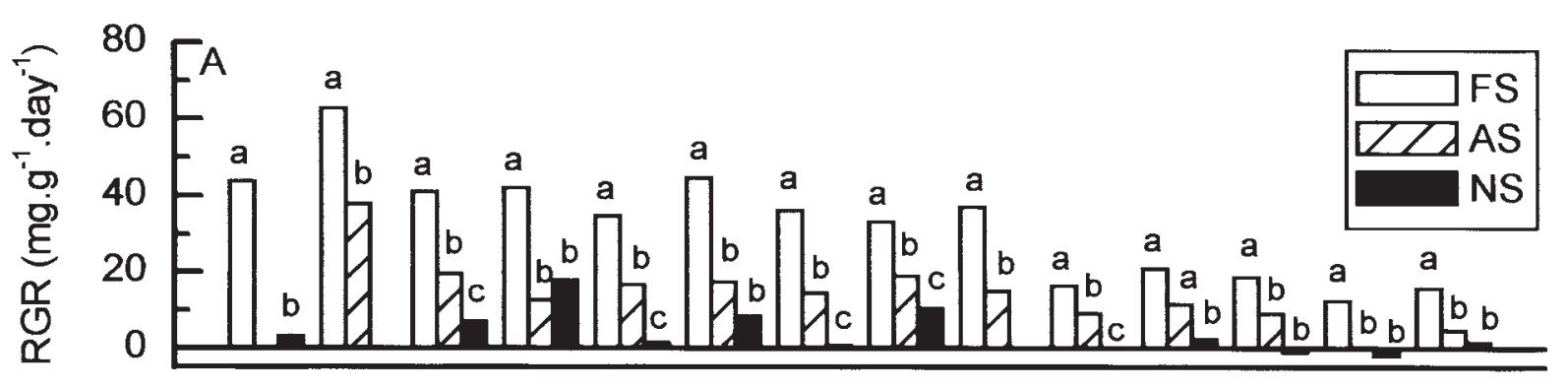

Sol Tre Cec Bau Sen Sch Pip Cho Pse Fic Ese Pac Myr Hym

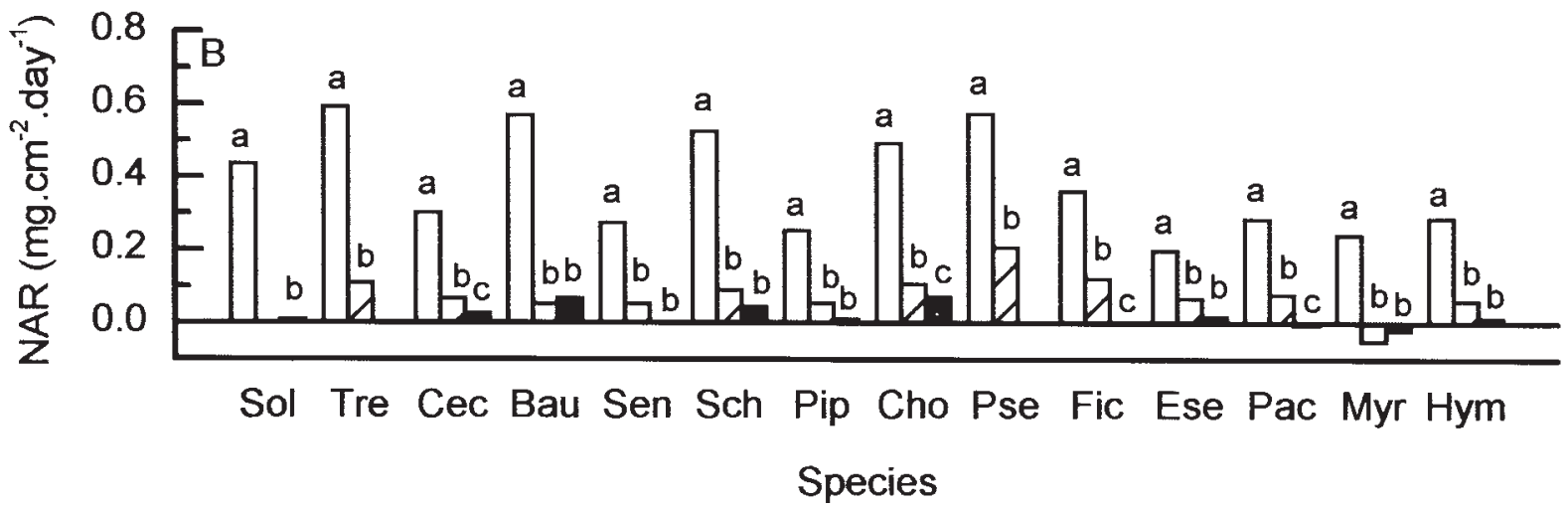

Figure 3. A. Relative growth rate (RGR) and B. net assimilation rate (NAR) of the studied tree species under full sun (FS, $\square$ ), artificial shade (AS, $\square$ ) and natural shade (NS, $\mathbf{\square})$ treatments. Measurements for 0-100 days time interval. Sol $=$ Solanum, Tre $=$ Trema, $\mathrm{Cec}=$ Cecropia, $\mathrm{Bau}=$ Bauhinia, $\mathrm{Sen}=$ Senna, $\mathrm{Sch}=$ Schizolobium, Pip $=$ Piptadenia, Cho $=$ Chorisia, Pse $=$ Pseudobombax, $\mathrm{Fic}=$ Ficus, Ese $=$ Esenbeckia, $\mathrm{Pac}=$ Pachystroma, $\mathrm{Myr}=$ Myroxylon, $\mathrm{Hym}=$ Hymenaea . Values followed by the same letter are not significantly different.

the late-successional species continued in the latter positions (i.e., lower RGRs). So, in general, there was a tendency for species with high RGR in high irradiance to show a relatively high RGR in shade. For example, among all species, Trema presented the highest RGR in FS as well as in AS. On the other hand, in all treatments, Myroxylon was among the species with the lowest growth rates. Considering all species, significant correlations between RGR values under FS and AS ( $\mathrm{r}=$ $0.91 ; \mathrm{p}<0.001)$ or NS $(\mathrm{r}=0.65 ; \mathrm{p}<0.05)$ were found.

\section{Discussion}

Effects of shading - Most of the studied species survived in both shade treatments, although their growth was severely affected. As reported in other studies (Augspurger 1984, Court \& Mitchell 1989, Kwesiga \& Grace 1986, Popma \& Bongers 1988, Osunkoya \& Ash 1991), plants in shade had lower height, internode number, leaf area and dry mass compared with sunexposed plants. For six of the studied species, RGR was reduced more in NS than AS, probably because the NS treatment was more severe than AS treatment as a result of a slightly lower irradiance. However, in general, there were no significant differences between AS and NS treatments in relation to final dry mass values, indicating that the PAR differences between these treatments had no marked effects on growth. Leaf area was also generally more severely affected by NS treatment than AS treatment, indicating the influence of the lower R:FR ratio of the NS treatment on leaf area. Reduced leaf development is one of the responses that may be evoked by phytochrome under conditions of reduced R:FR ratio (Smith \& Whitelam 1990). Internode elongation, with accompanying increase in height, is a response that is expected to occur under conditions of natural shade, because it is a typical morphogenic response (Smith \& Whitelam 1990). However, internode elongation was observed only in some late-successional species and it was not accompanied by height increase. It is possible that this morphogenic response was limited by the lack of photoassimilates as a result of the low photon flux 
density prevailing in NS. It has been shown that the rate of photosynthesis at low flux rates can limit the capacity of seedlings to respond to low R:FR ratios by increased extension growth (Smith \& Hayward 1985). Consistent with this hypothesis, Bartlett \& Remphrey
(1998) found that, in Fraxinus pennsylvanica, a temperate shade tolerant species, although moderate reductions in PAR led to increases in overall shoot length, heavy shading produced plants with little height growth. Our results showed that early-successional
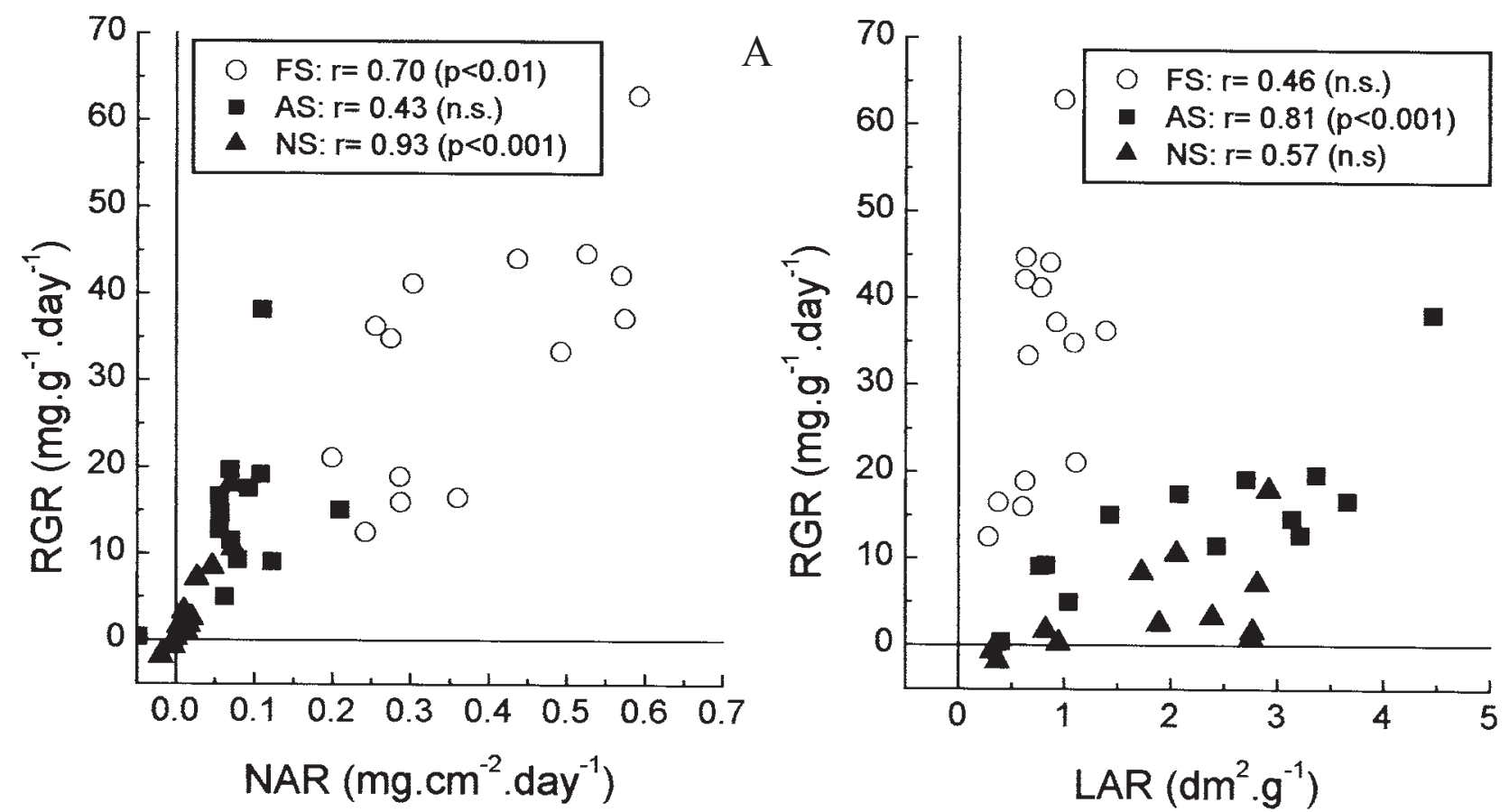

B
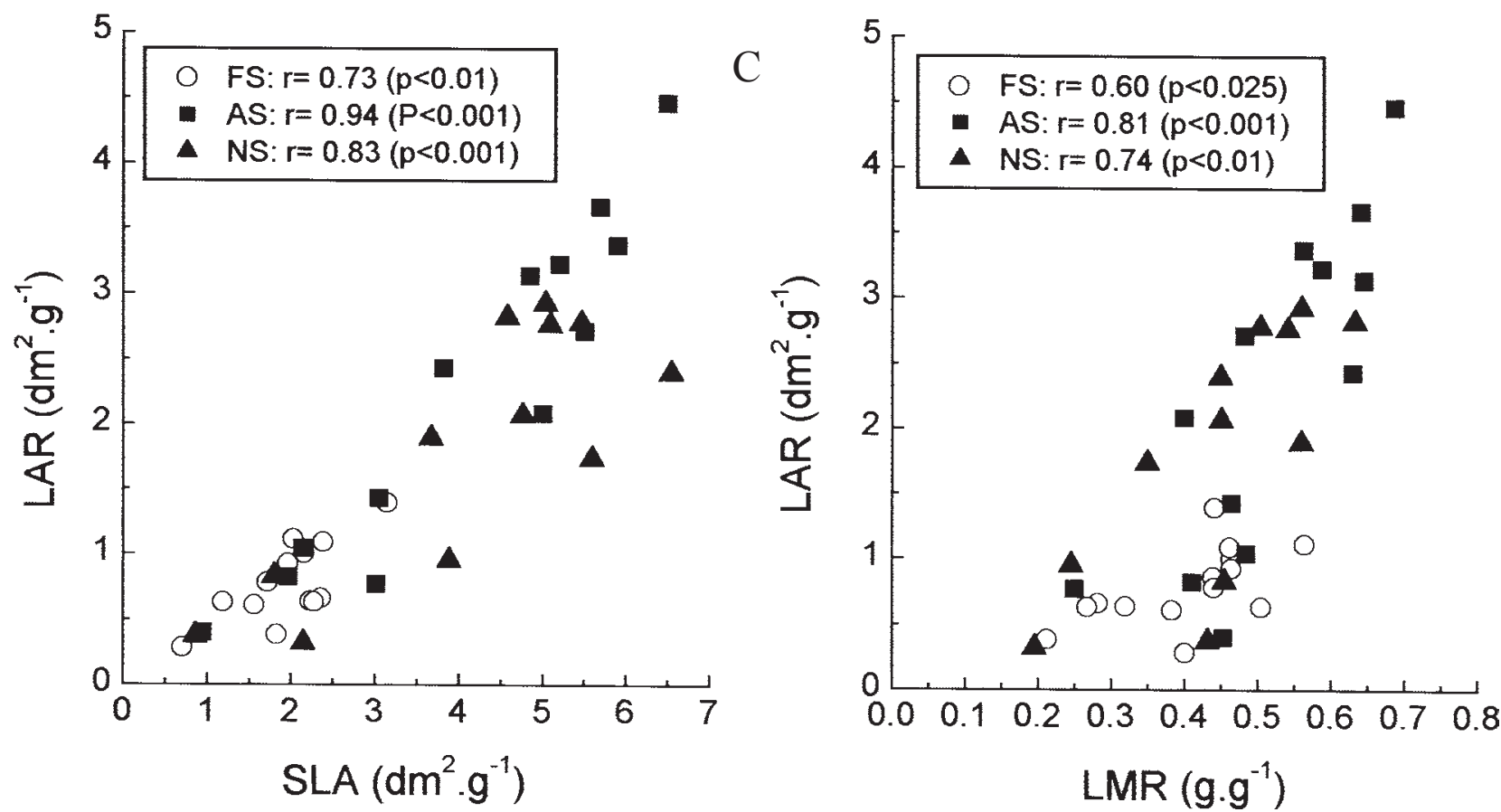

Figure 4. Correlation between RGR and NAR (A); RGR and LAR (B); LAR and SLA (C); and LAR and LMR (D). Pooled data of all species under each one of the treatments $(F S=$ full sun; $A S=$ artificial shade, $N S=$ natural shade $) . R G R=$ relative growth rate, $\mathrm{NAR}=$ net assimilation rate, $\mathrm{LAR}=$ leaf area ratio, $\mathrm{LMR}=$ leaf mass ratio. 
species seemed to suffer a greater shade-induced impairment of their height growth than late-successional species. Probably, this kind of response may have emerged as a result of the higher potential growth presented by early-successional species compared to late-successional ones, since acclimation potential seems to be closely related to maximal potential growth, as discussed by Chazdon (1992).

Other responses presented by the plants under both shade conditions included lower R:S and higher LAR, LMR and SLA, with no distinct treatments differences between AS and NS. This growth pattern has been observed by others (Popma \& Bongers 1988, 1991, Walters et al. 1993, Osunkoya et al. 1994, Reich et al. 1998) and is considered an adaptation to shade. It is assumed that these responses taken together can increase the ratio of photosynthesis to respiration at the whole-plant level and contribute to the maintenance of a positive carbon balance and maximization of growth in shade (Kitajima 1994). In this context, the response of Pachystroma to shade, i.e., decreased LMR and LAR, may have been harmful to the maintenance of a positive carbon balance of the plants. This could be the reason for the high mortality of this species inside the forest.

The shade-induced reductions of RGR were expected, because decreased PAR results in a reduction in photosynthesis. In fact, low NARs were also observed for all species in response to shade. However, according to Lambers \& Poorter (1992), RGR can vary not only as a function of NAR (its physiological component) but also as a function of LAR (its morphological component). For plants grown in the FS and NS treatments, we found a significant correlation between RGR and NAR, but no correlation between RGR and LAR. This indicates that the interspecific variation in growth in either high light or in forest understorey is mainly explained by the physiological component, largely determined by the photosynthetic activity of the plants. However, in the AS treatment, RGR was closely correlated with LAR but not with NAR. It follows that, in this case, morphological components, with emphasis on leaf area, are the main factors determining growth rate in light-limited conditions. These discrepancies in the correlations for AS and NS treatments may have occurred as a function of differences in the spectral quality of radiation. As leaf development is relatively more impaired in NS than AS conditions, as already discussed, it seems possible that, in NS, the morphological component of RGR was impaired and hence only a correlation with NAR have resulted. Nevertheless, interspecific variation in LAR, in all conditions, was explained by variations in SLA as well as in LMR, indicating that both leaf thickness and biomass allocation to leaves were important factors in determining the morphological alterations. Contrasting results in relation to the determinants of RGR have been found in other studies. Osunkoya et al. (1994) and Reich et al. (1998) found that RGR was correlated not only with NAR but also with LAR. Poorter (1999), based on results obtained with 15 rain-forest tree species, suggested that the different components of RGR become important at different irradiances. It was found that, at low light, species differences in RGR were mainly due to LAR and, at high light, they were mainly due to NAR. So, Poorter (1999) suggested that variations in morphology rather than physiology could be more important in determining growth in shaded understories. However, Poorter's (1999) study involved only neutral shade. Although the same conclusion was reached here when looking to the results obtained with the artificial shade, it seems that differences in behavior may arise under conditions of shade involving alterations of the spectral quality of light, which is the natural condition in the forest understories. Thus, under these latter conditions, it may be concluded here that the physiological response appeared to be a more important determinant of RGR than the morphological response. Comparison among species - Species with high growth rates were mainly those from early-successional positions, such as Trema, Solanum, Cecropia and Schizolobium. On the other hand, the late-successional Ficus, Pachystroma, Myroxylon and Hymenaea stood out with the smallest increments in several growth parameters as well as a low RGR and NAR in any condition. Such results are consistent with observations that species with high RGR under full radiation also maintain high RGR under shade (Poorter 1999, Kitajima 1994). There has been some controversy whether shade tolerant species perform better than pioneer under low light conditions. Popma \& Bongers (1988), for instance, ranked ten species according to the RGR presented by plants maintained under a forest canopy. Such ranking, from the lower to the higher value, matched the ecological sequence from pioneer to shade-tolerant species. However, such a criterion, if applied in the present study, would invalidate the sequence, placing pioneer species, such as Trema and Cecropia, in the group of shade-tolerant species. In the present study, there was a tendency for early-successional species to present higher growth rates than late-successional ones, regardless of light environment, and, in fact, significant correlations were found between growth in FS and 
shade treatments. Other studies comparing species from different successional positions also confirm higher growth for early shade-intolerant than for late shadetolerance species (Poorter 1999, Walters et al. 1993, Osunkoya et al. 1994, Reich et al. 1998). It seems, therefore, that the characteristic RGR from each species under a certain condition reflects its successional position, although the utilization of this or any other growth parameter, when isolated, requires caution. Moreover, in contrast to other studies where lower SLA, LAR and LMR and higher R:S were observed for shadetolerant in comparison with shade-intolerant species (Rao \& Singh 1989, Kitajima 1994), no consistent trend regarding successional positions was found. In a study with nine boreal tree species, Reich et al. (1998) also failed to find any correlation between successional status and biomass allocation or LMR, yet they still observed significant correlations with respect to SLA and LAR. DeLucia et al. (1998) also did not find any association of SLA and LAR with shade tolerance status. According to these authors, inconsistencies in relating these parameters to shade tolerance rankings may arise because there are a series of other factors, beyond light, that may influence the pattern of growth. Thus, these parameters can not be safely associated with shade tolerance, except in specific cases where they are clearly shown to vary consistently with some shade tolerance ranking. Kitajima (1994) points out that these traits are better correlated with survivorship in shade and not just with the reputed successional class of species. It is possible that the lack of a consistent trend of variation of these parameters may have emerged here because of the attempt to correlate them with the successional position of the species at adult stage, as species requirements and even growth responses may change with ontogeny (Clark \& Clark 1992). Despite these considerations, the RGR still seems to vary consistently with the successional ranking, as discussed above. Additionally, it was observed that the latesuccessional species showed less pronounced responses to shade, as evidenced by the results obtained for Myroxylon, Ficus, Esenbeckia, Pachystroma and Hymenaea. Despite showing some typical shade responses, these species did it to a smaller extent than observed for the early-successional species. Similar behavior was observed in other studies for other latesuccessional or shade-tolerant species (Fetcher et al. 1983, Kwesiga \& Grace 1986, Osunkoya et al. 1994). It may be that this different extent of responses of earlyand late-successional species is a consequence of differences in the species growth potential. Chazdon
(1992) has discussed that light-demanding species, with their great potential growth rates, suffers a kind of starvation response in shade, whereas the response of shade-tolerant species to high light may be limited by genetic constraints on maximal rates of response. Nonetheless, it seems that the low growth rates and the low extent of response of late-successional species is associated with shade tolerance. Changes in developmental pattern may not confer any advantage in densely shaded environments, where growth alterations would not increase the probability of increased light interception (Holmes \& Smith 1977). It is important to emphasize here that none of the studied species grew better under shaded environments. Indeed, there is evidence that most species depend on gaps, or at least benefit from them, for successful establishment (Denslow 1980), that is, the higher irradiance in gaps results in better growth, regardless of the ecological category (Chandrashekara \& Ramakrishnan 1993). As suggested by Augspurger (1984) and Kitajima (1994), late-successional species could be more capable of persisting under the canopy in a suppressed growth condition due to their lower growth rates. The lower RGRs and the low extent of response observed in this study for the late-successional species may support this view. Indeed, low potential growth has been associated with shade tolerance (Poorter 1999), which seems to be more concerned with the ability to survive for extended periods in deep shade than with the capacity of maximizing growth (Grime 1977). The persistence under a dense canopy could contribute to the build-up of a seedling bank, whose seedlings would benefit from increases in irradiance after gap formation.

Acknowledgements - We thank Dr. Jurandir Zullo Junior for measurements of the spectral distribution of radiation and Dr. Ladaslav Sodek for reviewing the English version of the manuscript. We also thank Fundação José Pedro de Oliveira for permission to work at the Santa Genebra Reserve. R.P. Souza was supported by Capes.

\section{References}

AUGSPURGER, C.K. 1984. Light requirements of neotropical tree seedlings: a comparative study of growth and survival. Journal of Ecology 72:777-795.

BARTLETT, G.A. \& REMPHREY, W.R. 1998. The effect of reduced quantities of photosynthetically active radiation on Fraxinus pennsylvanica growth and architecture. Canadian Journal of Botany 76:1359-1365.

BAZZAZ, F.A. 1979. The physiological ecology of plant succession. Annual Review of Ecology and Systematics 10:351-371. 
BERNACCI, L.C. \& LEITÃO FILHO, H.F. 1996. Flora fanerogâmica da floresta da Fazenda São Vicente, Campinas, SP. Revista Brasileira de Botânica 19:149-164.

CHANDRASHEKARA, U.M. \& RAMAKRISHNAN, P.S. 1993. Gap phase regeneration of tree species of differing successional status in a humid tropical forest of Kerala, India. Journal of Bioscience 18:279-290.

CHAZDON, R.L. 1992. Photosynthetic plasticity of two rain forest shrubs across natural gap transects. Oecologia 92:586-595.

CHAZDON, R.L. \& FETCHER, N. 1984. Light environments of tropical forests. In Physiological ecology of plants of the wet tropics (E. Medina, H.A. Mooney \& C. Vázquez-Yanes, eds.). Dr. W. Junk Publishers, The Hague, p.27-36.

CLARK, D.A. \& CLARK, D.B. 1992. Life history diversity of canopy and emergent trees in a neotropical rain forest. Ecological Monographs 62:315-344.

COURT, A.J. \& MITCHELL, N.D. 1989. The growth responses of Dysoxylum spectabile (Meliaceae) to a shaded environment. New Zealand Journal of Botany 27:353-357.

DELUCIA, E.H., SIPE, T.W., HERRICK, J. \& MAHERALI, H. 1998. Sapling biomass allocation and growth in the understory of a deciduous hardwood forest. American Journal of Botany 85:955-963.

DENSLOW, J.S. 1980. Gap partitioning among rainforest trees. Biotropica 12 (supplement):47-55.

FETCHER, N., STRAIN, B.R. \& OBERBAUER, S.F. 1983. Effects of light regime on the growth, leaf morphology and water relations of seedlings of two species of tropical trees. Oecologia 58:314-319.

GANDOLFI, S. 1991. Estudo florístico e fitossociológico de uma floresta residual na área do Aeroporto Internacional de São Paulo, Município de Guarulhos, SP. Dissertação de mestrado, Universidade Estadual de Campinas, Campinas.

GANDOLFI, S., LEITÃO FILHO, H.F. \& BEZERRA, C.L.F. 1995. Levantamento florístico e caráter sucessional das espécies arbustivo-arbóreas de uma floresta mesófila semidecídua no município de Guarulhos, SP. Revista Brasileira de Biologia 55:753-767.

GRIME, J.P. 1977. Evidence for the existence of three primary strategies in plants and its relevance to ecological and evolutionary theory. American Naturalist 111:1169-1194.

HARTSHORN, G.S. 1980. Neotropical forest dynamics. Biotropica 12 (supplement):23-30.

HOLMES, M.G. \& SMITH, H. 1977. The function of phytochrome in the natural environment. IV. Light quality and plant development. Photochemistry and Photobiology 25:551-557.

HUNT, R. 1982. Plant growth curves. The functional approach to plant growth analysis. Edward Arnold, London.
KITAJIMA, K. 1994. Relative importance of photosynthetic traits and allocation patterns as correlates of seedling shade tolerance of 13 tropical trees. Oecologia 98:419-428.

KWESIGA, F. \& GRACE, J. 1986. The role of the red/far-red ratio in the response of tropical tree seedlings to shade. Annals of Botany 57:283-290.

LAMBERS, H. \& POORTER, H. 1992. Inherent variation in growth rate between higher plants: a search for physiological causes and ecological consequences. Advances in Ecological Research 23:187-261.

LEE, D.W., BASKARAN, K., MANSOR, M., MOHAMAD, H. \& YAP, S.K. 1996. Irradiance and spectral quality affect Asian tropical rain forest tree seedling development. Ecology 77:568-580.

LILLIEFORS, H. 1967. On the Kolmogorov-Smirnov test for normality with mean and variance unknown. Journal of American Statistical Association 62:399-402.

LORENZI, H. 1992. Árvores brasileiras. Manual de identificação e cultivo de plantas arbóreas nativas do Brasil. Editora Plantarum, Nova Odessa.

MANTOVANI, W. 1993. Estrutura e dinâmica da floresta atlântica na Juréia, Iguape, SP. Tese de livre-docência, Universidade de São Paulo, São Paulo.

OSUNKOYA, O.O. \& ASH, J.E. 1991. Acclimation to a change in light regime in seedlings of six Australian rainforest tree species. Australian Journal of Botany 39:591-605.

OSUNKOYA, O.O., ASH, J.E., HOPKINS, M.S. \& GRAHAM, A.W. 1994. Influence of seed size and seedling ecological attributes on shade-tolerance of rainforest tree species in northern Queensland. Journal of Ecology 82:149-163.

POPMA, J. \& BONGERS, F. 1988. The effect of canopy gaps on growth and morphology of seedlings of rain forest species. Oecologia 75:625-632.

POPMA, J. \& BONGERS, F. 1991. Acclimation of seedlings of three Mexican tropical rain forest tree species to a change in light availability. Journal of Tropical Ecology 7:85-97.

POORTER, L. 1999. Growth responses of 15 rain-forest tree species to a light gradient: the relative importance of morphological and physiological traits. Functional Ecology 13:396-410.

RAMAKRISHNAN, P.S., SHUKLA, R.P. \& BOOJH, R. 1982. Growth strategies of trees and their application to forest management. Current Science 51:448-455.

RAO, P.B. \& SINGH, S.P. 1989. Germination of certain climax and successional Hymalayan trees as affected by moisture gradient: implications for revegetation of bare areas. Tropical Ecology 30:274-284.

REICH, P.B., TJOELKER, M.G., WALTERS, M.B., VANDERKLEIN, D.W. \& BUSCHENA, C. 1998. Close association of RGR, leaf and root morphology, seed mass and shade tolerance in seedlings of nine boreal tree species grown in high and low light. Functional Ecology 12:327-338. 
RODRIGUES, R.R. 1995. A sucessão florestal. In Ecologia e preservação de uma floresta tropical urbana: Reserva de Santa Genebra. (P.C. Morellato \& H.F. Leitão Filho, eds.). Editora da Unicamp, Campinas, p.30-35.

SALIS, S.M., TAMASHIRO, J.Y. \& JOLY, C.A. 1994. Florística e fitossociologia do estrato arbóreo de um remanescente de mata ciliar do rio Jacaré-Pepira, Brotas, SP. Revista Brasileira de Botânica 17:93-103.

SOUZA, R.P. \& VÁLIO, I.F.M. 2001. Seed size, seed germination and seedling survival of Brazilian tropical trees differing in successional status. Biotropica 33:447-457.

SMITH, H. 1992. The ecological functions of the phytochrome family. Clues to a transgenic programme of crop improvement. Photochemistry and Photobiology 56:815-822.

SMITH, H. \& HAYWARD, P. 1985. Fluence rate compensation of the perception of red:far-red ratio by phytochrome in light-grown seedlings. Photochemistry and Photobiology 42:685-688.

SMITH, H. \& WHITELAM, G.C. 1990. Phytochrome, a family of photoreceptors with multiple physiological roles. Plant Cell and Environment 13:695-707.
SWAINE, M.D. \& WHITMORE, T.C. 1988. On the definition of ecological species groups in tropical rain forests. Vegetatio 75:81-86.

THOMPSON, W.A., KRIEDEMANN, P.E. \& CRAIG, I.E. 1992. Photosynthetic response to light and nutrients in suntolerant and shade-tolerant rainforest trees. I. Growth, leaf anatomy and nutrient content. Australian Journal of Plant Physiology 19:1-18.

TINOCO-OJANGUREN, C. \& PEARCY, R.W. 1995. A comparison of light quality and quantity effects on the growth and steady-state and dynamic photosynthetic characteristics of three tropical tree species. Functional Ecology 9:222-230.

WALTERS, M.B., KRUGER, E.L. \& REICH, P.B. 1993. Growth, biomass distribution and $\mathrm{CO}_{2}$ exchange of northern hardwood seedlings in high and low light: relationship with successional status and shade tolerance. Oecologia 94:7-16.

WANG, G.G., QIAN, H. \& KLINKA, K. 1994. Growth of Thuja plicata seedlings along a light gradient. Canadian Journal of Botany 72:1749-1757. 